English Studies
ONIVERSITY OF MURCIA

\title{
Resisting Borders: Transnational Cartographies in US Latinx Studies ${ }^{1}$
}

\author{
MACARENA GARCÍA-AVELLO* \\ University of Cantabria (Spain)
}

Received: 22/03/2020. Accepted: 08/02/2021.

\begin{abstract}
This article examines the evolution of the borderlands as an organizing trope by focusing on how the transcendence beyond cultural nationalist perspectives traces the shift from Chicano/a to Latinx discourses. In order to address this issue, I will analyse two twenty-first-century Latinx texts that delve into the intricate ways in which transnational forces collide with economic, cultural and political processes that persistently revolve around the framework of the nation-state: Alicia Gaspar de Alba's Desert Blood: The Juarez Murders (2005) and Maya Chinchilla's The Cha Cha Files: A Chapina Poética (2014). The corpus of works selected will focus on the political readings derived from textual negotiation with a changing political, social and economic reality. This results in constant tensions between globalising processes, worldwide interconnectedness and transnational interactions, on the one hand, and the regulatory power of the state, on the other.
\end{abstract}

KEYWORDS: Borderlands; Transnationalism; Chicano/a; Latinx; Globalisation; Nation.

\section{INTRODUCTION TO THE SPANISH BORDERLANDS}

The history of the US cannot be properly understood without reference to the Mexican border. In his 1921 volume, Herbert Bolton's studies on what he calls the "Spanish Borderlands", States "written almost solely from the standpoint of the East and of the English colonies" (qtd. in Hanke, 1964: 25). In The Rhizomatic West: Representing the American West in a Transnational, Global, Media Age, Neil Campbell states that the West was initially associated with a straight line that materialised in "road, frontier, grid, linear history and narrative, monologue" (2008: 28). However, the influence of the Mexican borderlands imbued "the once near-mythic narratives of conquest and cowboys" (Lytle Hernández, 2011: 327) with hybridism derived from migratory circuits, transnational cultural practices and flows. This

*Address for correspondence: Macarena García-Avello, Department of Philology, University of Cantabria, Spain; e-mail: gavellom@unican.es 
contributed to an understanding of the American West as a space that Campbell described as a "rhizomatic third space" (2008) and Saldívar as a "transfrontera contact zone" (1997). The linearity of this region was, in Campbell's words, "disrupted by the trope of crossing (dialogue, diaspora, rhizome, the fold)" (2008: 28).

The interplay and exchanges between the two neighbouring countries, along with the influence of Mexico and the population of Mexican descent, reshaped American literature. In particular, US Latinx Studies contributed to representations of the borderlands as not just a geopolitical space, but also as a junction where opposing systems coalesce, clash and interweave. This article examines the evolution of the borderlands as an organizing trope by focusing on how the transcendence beyond cultural nationalist perspectives traces the shift from Chicano/a to Latinx discourses. While the term "Chicano/a" emerged as a collective identity marker rooted in the Chicano Social Movement, which later expanded to designate Mexican Americans in general, the ethnic label Latina/o refers to any person of Latin American heritage. The term Latinx, on the other hand, was coined in the twenty-first century to offer more inclusive categories through which gender as a binary concept could be transcended. Contemporary Latinx Studies has been shaped by two main factors: the affirmation of a transnational paradigm and the literary and commercial success from the 80s onwards of authors like Sandra Cisneros, Julia Álvarez, Cristina García and Esmeralda Santiago, among others, which led to what has been described as a "mainstreaming of Latinx literature in the US literary market" (Smith \& Franco, 2018: 5).

The question that emerges, and which will be explored throughout this article, is how these changes have had an impact on a generation of Latinx writers whose work is being published and read in the twenty-first century. In order to address this issue, I will analyse two twenty-first-century Latinx texts that delve into the intricate ways in which transnational forces collide with economic, cultural and political processes that persistently revolve around the framework of the nation-state: Alicia Gaspar de Alba's Desert Blood: The Juarez Murders (2005) and Maya Chinchilla's The Cha Cha Files: A Chapina Poética (2014). While the corpus of works selected in this essay is limited due to space restrictions, the two literary texts included offer new and insightful approaches to the borderlands as a transnational space, resonating with Schmidt Camacho's understanding of the transnational as "the space in which distinct national localities are linked together by migratory flows, and the diaspora formed by this migration (...) as migrants narrate a condition of alterity to, or exclusion from, the nation, they also enunciate a collective desire for a different order of space and belonging across the boundary. Their narratives imaginatively produce forms of communal life and political organization in keeping with their fragile agency as mobile people" (2008: 5).

Schmidt Camacho's quotation points towards the political underpinnings of transnational representations like the ones included in this article. The interplay between transnationalism and US Latinx literature has been widely explored. Nevertheless, the tension 
between nationalist approaches to the materiality of the US-Mexico border and Latinx representations of an increasingly globalised world has not been sufficiently studied. Therefore, the corpus of works selected will focus on the political readings derived from textual negotiation with a changing political, social and economic reality. This results in constant tensions between globalising processes, worldwide interconnectedness and transnational interactions, on the one hand, and the regulatory power of the state, on the other.

\section{FROM CHICANO CULTURAL NATIONALISM TO CHICANA BORDERLANDS}

In order to address the tensions that exist between transnational and cultural nationalist perspectives, this first section will offer an overview of the political underpinnings of cultural nationalist narratives associated with the Mexican American Civil Rights Movements. Within the context of the Civil Rights Movements of the 60s, the population of Mexican descent joined in a social protest movement against the discrimination they suffered as members of ethnic minorities. In the South West, particularly in California, the Chicano Movement emerged as a response to the social injustice, political inequality and segregation, which provided them, as Amaya Ibarraran indicates, with "an exceptionally effective means to proclaim and demand the rights of this silenced community in the eyes of mainstream, accommodated US society, and, most importantly, to raise the social, cultural and ethnic consciousness" (2009: 36). Although the origins of the term "Chicano/a" are unclear ${ }^{2}$, it was used to distinguish MexicanAmericans from other US minority groups. In early Chicano scholarship, self-representation was essential to ethnic belonging, thus implying that art served as the basic source for promoting a collective identity. Furthermore, within the framework of this movement, also referred to as Chicano cultural nationalism, literature became an important channel to draw attention to the multiple discrimination and feelings of displacement experienced by this group.

This is the case of migrant farm workers, whose hardships were depicted in Tomás Rivera's Y no se lo tragó la tierra (1971). Besides denouncing the social problems encountered by the population of Mexican descent, early Chicano literature also tackled identity issues emanating from their position in-between two nations with conflicting centres of power. Seminal texts like José Antonio Villareal's Pocho (1959) reflects on how Chicanos encounter opposing fronts of hegemony that place them at the margins as members of an ethnic and racial minority in the Southwest. While the preservation of Mexican traditions and values in many cases prevents them from being assimilated to US culture, the inevitable contact with mainstream American society also challenges their self-identification as Mexicans. That is, the influence of the American context, along with a supposed "Americanisation", problematise their "authenticity" as Mexicans. Within a framework that resembles a "bipolar model of opposing cultures" (Sánchez, 1995: 7), border-crossing becomes a distinctive feature of the Chicano Movement, as the borderlands comes to represent a metaphor that captures life at the 
margins, in-between two languages, two cultures and two worlds shaping the subject's experience and self-formation.

The US context and the Mexican heritage function as conflicting dialectical forces involved in a narrative that culminates when both influences coalesce and fuse in the construction of a hybrid subjectivity ${ }^{3}$. Chicano/a literature uses the term "mestizaje" to identify the crafting of a mixed-blood self that embraces the dualisms derived from their liminal experiences. Francisco Lomelí reflects on this circumstance when he concludes that "people of Mexican descent have a rightful place they can claim their own that is both Mexican and Anglo American, which Chicanos synthesize in varying degrees" (qtd. in Vázquez, 2013: 302). An emblematic example of this ambivalence is Rodolfo Gonzales's poem, "Yo soy Joaquín" (1967). This poem resembles a journey between multiple dichotomies that are finally conjugated into the "cultura mestiza", a hybrid subjectivity that traverses the crafting of a Chicano self. "I look at myself/ And see part of me/ Who rejects my father and my mother/ And dissolves into the melting pot/ To disappear in shame (...) I am the masses of my people and/ I refuse to be absorbed. I am Joaquín" (qtd in Leonard \& Lugo-Lugo, 2010: 110). The narrator navigates a series of dualisms that become representative of the construction of subjects within Chicano cultural nationalism as border-crossers defying the confines of national boundaries.

Unable to preserve an essence unaffected by American influences, early Chicano authors construct a distinct space that corresponds to a bifocal perspective "positioned inside the borderlands" (Ethington, 1996: 348). In cases like Rudolfo Anaya's Bless me Última (1972), this identity quest led to the appropriation of the Bildungsroman genre, established in nineteenth-century Europe. Anaya's coming of age novel revises and adopts the Bildungsroman's structure in order to accommodate it to six-year-old Tony's rite of passage. The coexistence of elements pertaining to both Mexican and US culture forces the narrator to contend with the clashing centres of hegemony. The process of maturity culminates when he embraces the inherent conflicts, contradictions and ambiguities that emanate from the intersection between the Mexican and the American realities.

It is worth noting that most of these early texts were written and focused primarily on male subjectivities and the construction of a predominantly male identity. Within this framework, it is not surprising that even though many women had actively participated in the Chicano Movement, they soon realised that their voices were being silenced and their concerns and preoccupations ignored. While Chicano cultural nationalism defended the traditional family model as a symbol of cultural and political resistance against the dominant American culture (García, 1989:219), this model, as well as the influence of the Catholic Church, confined women to the domestic sphere and the prototypical roles available to them within patriarchal discourses. The marginal place occupied by women and feminist issues, along with 
the proliferation of sexist attitudes within the Chicano Movement, led Chicanas to look for alliances with second wave feminist movements.

Nevertheless, their disparate approaches to feminist analyses also proved an obstacle on the path towards potential coalitions between women. More specifically, Chicanas focused on the interaction that coexisting variables, such as gender, class, race and ethnicity, exert on women's discrimination. They criticised what they regarded as a reluctance on the part of hegemonic feminism to acknowledge differences between women, along with the distinct actions and responses these differences require. Their struggle to address sexism and racism, issues that affected them as members of racial and ethnic minority groups in the US, aligned them with African American women. In Zami (1982), Audre Lorde reflects on how race, sexuality, ethnicity and class have determined her political identity and activism in ways that differentiate her from mainstream feminism: "Being women together was not enough. We were different. Being gay-girls together was not enough. We were different (...) It was a while before we came to realize that our place was the very house of difference rather than the security of any one particular difference" (1982: 226). Throughout her work Lorde establishes a theoretical grounding for intersectional approaches, understanding gender, race and sexuality as interconnected, with no variable taking priority over the others. The recognition of common ground led Chicana feminists to join forces in order to build a political strategy based on coalitions between non-hegemonic feminisms.

Cherrie Moraga, a key figure within Chicana feminism, was particularly emphatic about the need to form alliances and bonds between women whose experiences are marked by their "difference", such is the case of Chicana feminist lesbians: "I am a woman with a foot in both worlds; and I refuse the split. I feel the necessity for a dialogue. Sometimes I feel it urgently" (Moraga, 1981: 27). Cherrie Moraga's quotation calls for opening up a dialogue between movements of women of color committed to opposing sexism, racism and homophobia. Efforts to forge alliances were reflected through the metaphor of the bridge in Gloria Anzaldúa and Cherrie Moraga's anthology of texts written by ethnic minority women, This Bridge Called my Back (1981). Chicana's estrangement from the conflicting hegemonic forces that contributed to their discrimination made flexibility and mobility essential components in their approach to feminism. The emphasis on strategic coalitions characterised women of color resistance movements in general and Chicano scholarship in particular.

Melissa Groenewold describes Chicanas' marginalised status as "an imposed oppression determined by her cultural allegiance, not only from the Anglo-dominant society in which she struggles to survive but also that oppression inflicted upon her from within her culture of origin" (2005: 92). The crossroads Chicanas encounter is explored in Gloria Anzaldúa's foundational text, Borderlands/ La frontera (1987). With the publication of Anzaldua's work, border-crossing and its connection to gender issues reaches a climax, marking the point of departure for Border Theory. The borderlands comes to represent both a 
geopolitical location "where two or more cultures edge each other, where people of different races occupy the same territory" (Anzaldúa, 1987: 1), as well as a metaphor for transitory states in-between multiple cultures, languages and worlds.

Anzaldúa reflects on both the material and discursive effects derived from the collision between two worlds that clash and intermingle, giving rise to an interstitial or third space where conflicting hegemonic discourses converge:

The US-Mexican border es una herida abierta where the Third World grates against the first and bleeds. And before a scab forms it haemorrhages again, the lifeblood of two worlds merging to form a third country -a border culture. Borders are set up to define the places that are safe and unsafe, to distinguish us from them. A border is a dividing line, a narrow strip along a steep edge. A borderland is a vague and undetermined place created by the emotional residue of an unnatural boundary. It is a constant state of transition. The prohibited and forbidden are its inhabitants. Los atravesados live here. (Anzaldúa, 1987: 25)

Anzaldúa focuses on a very specific location, the porous Texas-Mexico border, and on the particular situation of Chicanas, unequivocal examples of what she calls "atravesados", left stranded and alienated from two cultures that exert different forms of discrimination upon them; while the dominant Anglo American society devaluates their ethnic roots, their gender also relegates them to a marginal place within the Chicano community. Therefore, the borderlands is also equated with a third space where different axis of meaning are confronted, contested and deconstructed, aa metaphor for "liminal stages of transition", "disassociations of identity, identity breakdowns and buildups, and to intercultural impingement" (Anzaldúa qtd. in Román-Odio \& Sierra, 2011: 7).

Even though the border is conceived as a boundary that separates, divides and segregates, Anzaldúa acknowledges its potentiality as a space of resistance by emphasising its fluctuating and malleable nature. The ability to navigate multiple borders conditions the experiences of Chicana women, immersed in transitional states from which dominant discourses on gender, sexuality, genre, nation and ethnicity are interrogated, deconstructed and ultimately re/constructed according to alternate paradigms. Conventional labelling and epistemic categories are challenged in a process that leads Chicanas to cope with the ambiguities, contradictions and various centres of power until they forge a new form of consciousness, "the consciousness of the borderlands" or "new mestiza" (1987: 101). Anzaldúa defines this as a metaphorical space she creates for a self capable of rising beyond binary dualisms, "developing a tolerance for contradictions, a tolerance for ambiguity [...] Not only does she sustain contradictions, she turns the ambivalence into something else" (1987: 101). While area studies marked US academia from the second half of the twentieth century, 
Anzaldúa's work promoted the examination of hemispheric links and transnational flows as an academic methodology in the US. Her work played a central role in the new tendency Héctor Calderón and José David Saldívar described as "a new awareness of the historical and cultural interdependence of both northern and southern American hemisphere" (1991: 7). Anzaldúa's foundational text laid the theoretical grounding for border studies, Chicana feminism, and The Latina Literary Boom from the 80s. As discussed in the next section, Latino/a encompassed different minorities under an umbrella term denoting a Pan-Latin American common connection.

\section{THE LATINA LITERARY BOOM}

The proliferation of Chicana departments throughout the West Coast, particularly in California, coexists with the increasing popularity during the 80s and 90s of a group of Latina female writers from various origins. In Redreaming America (2005), Debra Castillo refers to this as a Latina literary boom that comprises not only Chicana writers like Sandra Cisneros, Ana Castillo, Graciela Limón, Demetria Martínez and Helena María Viramontes, but also authors from different national backgrounds, such as Cuban-born Cristina García, Dominicanborn Julia Álvarez and Esmeralda Santiago from Puerto Rico. Immigration, exile, displacement and bi/culturality are some of the recurring topics that characterise their literature, along with the representation of the multiple forms of discrimination experienced by Latina women.

Even though Anzaldúa's theory focuses on the particular situation of Chicanas or, as she calls them, mestizas, the theoretical grounding of Anzaldúa's borderlands has been extended to the analysis of the contacts, circuits and exchanges between the US and different Latin American and Caribbean countries. In Narrative Identities (2003), for example, Roland Walter devotes a chapter to explore the construction of an identity assimilated to the "conciencia mestiza" in Ana Castillo's The Mixquiahuala Letters (1986). In the same vein, García-Avello studies three canonical novels within US Latina Literature through the lens of Anzaldúa's epistemology (2019: 71): Cisneros's The House on Mango Street (1984), Álvarez's How the García Girls Lost Their Accent (1991) and García's Dreaming in Cuban (1992). The protagonists of all these novels feel emotionally detached from their community of origin, but they also problematise their belonging to the US, contributing to the implosion of national boundaries.

Like Anzaldúa, these commercially successful Latina writers complicate geographic, linguistic and cultural frontiers so that the borders that were so clearly theorised by cultural nationalist narratives become blurred. The aforementioned novels, along with other seminal texts written in the final decades of the twentieth century, like Ana Castillo's Sapogonia (1990), Demetria Martínez's Mother Tongue (1990) and Helena María Viramontes 's "The Cariboo's Cafe" (1995) envision a literary space based on hemispheric connections between 
the US and Latin America and the Caribbean, on the one hand, and also on the increasing contacts and networks between Latinx groups in the US. This second process corresponds to Frances Aparicio's use of "interlatinidades" as a category that reflects "the very complex and interestingly novel ways in which Latino/as from specific national groups get to know, and interact with, their cultural twins and national others" (2000: 6).

These novels are illustrative of an undetermined and evasive zone that resists nationcentred paradigms, as well as the establishment of simple and unequivocal identifications. The deconstruction of national categories in some of the Latina literary boom novels also extends to gender identity. In this sense, the main difference between the Latina Boom generation and the generation belonging to Chicano cultural nationalism is precisely the fact that monolithic and essentialist views on gender and sexualities are challenged through narratives that strive to transcend fixed and stable categories. Fatima Mujcinovic's essays in Postmodern CrossCulturalism and Politicization in US Latina Literature offer insightful analyses on how national and gender discourses are contested by some of the aforementioned Latina boom authors, like Ana Castillo, Cristina García, Graciela Limón, Demetria Martínez and Julia Álvarez. Their literary works exhibit representations of the borderlands as a metaphorical third space, "the interstices" from which dominant discourses on gender, sexuality, genre, nation and ethnicity are interrogated and ultimately deconstructed. As a consequence, the borderlands turns from "a site of entrapment into a space of liberation, generating multiple sources of identification and strategies of differential agency" (Mujcinovic 2004: 11).

The borderlands in Anzaldúa necessarily implies, and has indeed contributed to, a transnational paradigm shift in Chicano/a and US Latina literature. But not only Anzaldúa, the Latina Boom authors also paved the way for a transnational literary space based on hemispheric connections, the convergence of transnational imaginaries and narratives opening a "global connectivity discourse" (Ramamurthy, 2003: 527) in the twenty-first century. Since 2015, the use of the term "Latinx" has become widespread on the Internet and other sociocultural contexts. Referring to Latinas/os in the United States, the term not only problematizes national categories associated with Latinidades but also suggests a more inclusive vision of gender and sexual identities that transcends heteronormative binaries. The " $x$ " in "Latinx" deconstructs gender binarism, pointing to a more flexible and expansive spectrum of gender and sexual identities in the context of transnational cultural formations that will be examined in the following section.

\section{TRANSNATIONAL SHIFT}

From the beginning of the twenty-first century, the increasing migratory circuits, globalising processes, as well as the development of communication technologies have promoted the intensification of transnational flows both inside and outside the US, resulting in the transnational paradigm described by Vertovec as "a condition in which, despite great 
distances and notwithstanding the presence of international borders (and all the laws, regulations and national narratives they represent), certain kinds of relationships have been globally intensified and now take place paradoxically in a planet-spanning yet common however virtual- arena of activity" (2009: 3). The rising pace of globalisation and developments in transport, communications and technologies have also contributed to the proliferation of literary representations of transnational circuits, exchanges and flows between nations in Latinx texts in the twenty-first century.

According to Saldívar, US Latinx Studies disrupted area studies by pointing towards more flexible approaches beyond national borders. This is partly due to the fact that from its inception, US Latinx studies have been placed in an undetermined and evasive zone that resists nation-centred paradigms. As a collective identity marker, Latinx can only be understood according to a transnational paradigm shift, for rather than establishing classifications based on essentialist attitudes inherent in national identification, it alludes to "an imagined, transnational and communal formation" (Rodríguez, 2002: 120). An earlier text that critically and explicitly reflects on this movement beyond original cultural nationalist claims and cultural productions is "Chicana! Rican? No, Chicana-Riqueña!' Refashioning the Transnational Connection", in which Chabram-Dernersesian draws on her own experience as grand-daughter of a Puerto Rican and a Chicana woman. Her hybrid heritage exposes national identifications as narrow and essentialist, calling for more inclusive forms of identification. The proliferation of contacts and exchanges between different Latinx subgroups complicates close and hermetically sealed categories, which differentiates them from earlier generations, who, according to the author, "would not anticipate a kind of transnational migration that their grandchildren would consciously assume generations later as a way of tracing different ethnic ancestries and cultural identities denied to them " (1994: 273). Furthermore, the fact that her article is rooted in her own genealogy also prevents her from overlooking real and specific differences between subgroups.

In the same vein, the local, regional, national, cultural and ethnic differences that distinguish subgroups and individuals under the umbrella term "Latinx" are reflected through literary representations like the ones studied in the following section. While Latinx functions, in Aparicio's words, "as strategic and functional 'essentialisms' that are used in order to organize movements and increase social power" (2003: 28), US Latinx literature has the power to offer varied and rich representations of what is meant by an ethnic label that defies gender binaries. In Critical Latin American and Latino Studies (2003), Poblete considers Latinx Studies as representative of a "new Americanism" that challenges the underlying colonialism traversing ethnic and area studies. In Poblete's words, it "posits itself as the analytical space where borders themselves can be investigated and with them all kinds of transnational, translingual, and transcultural phenomena" (2003: xv). Furthermore, the term Latinx takes into account a new dimension by embracing greater inclusivity of gender and sexuality. 
The correlation between the deconstruction of national discourses and dominant discourses on gender has received considerable scholarly attention. Following this current, Jacqui Alexander's Pedagogies of Crossing adopts a transnational approach to "multiple operations of power, of gendered and sexualized power that is simultaneously raced and classed yet not practiced within hermetically sealed or epistemically partial borders of the nation state" (Alexander 2005: 5). On the other hand, Laura Briggs, Gladys McCormick and J.T. Way's article "Transnationalism: A Category of Analysis" contends that the proliferation of transnational studies has caused certain conceptual confusion, even contradictory readings and analyses. In order to advocate for what they consider to be a productive paradigm, they introduce a theoretical framework that allows them to articulate their understanding of the term. Their approach establishes an analogy between gender as a construction in women's studies and nation as a constructed entity in transnationalism. In their own words, "transnationalism' can do to the nation what gender did for sexed bodies: provide the conceptual acid that denaturalizes all their deployments, compelling us to acknowledge that the nation, like sex, is a thing contested, interrupted, and always shot through with contradiction" (2008: 627).

Taking this as a starting point, the authors defend the thesis that the nation has to be de-naturalised and challenged. However, the correlation to gender reminds us that thinking beyond the confines of national borders is not so simple in the globalised era, in the same way that the materiality of the body contributes to the illusion that there is some concatenation between biological and socio-cultural phenomena. In this sense, gender binary has remained a pervasive idea, in spite of the efforts on the part of gender studies to show how sexed bodies are also constructed. Furthermore, the realisation that gender and nation are constructions does not do away with their effects, and even though political borders tend to be flexible for multinational corporations, they are not for common citizens. In other words, despite the proliferation of transnational approaches, the nation continues to exert a huge influence.

Regarding twenty-first-century Latinx literature, the transnational paradigm shift raises questions on how representations of the borderlands in the new era of globalisation conjugates with the materiality of the Mexico-US border, shaped by political, economic and cultural processes. In the same vein, Yarbro-Bejarano anticipated some of these issues when she questioned whether translating Anzaldúa's theoretical framework to different Latinx contexts could also lead to misconstrued and depoliticised readings; in her own words, "what is lost in terms of the erasure of difference and specificity?" (1994: 8). Contemporary transnational Latinx literature must negotiate a complicated balance between the need to consider the regulatory power of the state and the study of global power relations that go beyond national frameworks. This interplay between global, national and regional forces is regarded by Caren Kaplan, Norma Alarcón and Minoo Moallen in Between Women and Nation, as an open-ended negotiation "between the national, the global and the historical as well as the contemporary 
diasporic" (1999: 360). The corpus of texts studied in the following section indicate an outlook on transnational feminism that is characterised by its scepticism and problematisation of the notion of the nation-state, gender categories and globalisation, understood as "a complex economic, political, cultural, and geographic process in which the mobility of capital, organizations, ideas, discourses, and people has taken on an increasingly global or transnational form" (Moghadam, 1999: 35). More specifically, globalisation is critically approached as an economic, political and cultural phenomenon in Desert Blood and Maya Chinchilla's collection of poems. Rather than assuming a neutral attitude towards globalising processes, the corpus of Latinx works selected interrogates the different and complex manners in which women's lives and subjectivities are influenced by transnational flows and circuits. Nevertheless, despite the proliferation of transnational perspectives, the following texts demonstrate the different ways in which the nation still exerts a huge influence.

\section{GLOBALISATION AND THE BORDERLANDS}

Alicia Gaspar de Alba's Desert Blood: The Juarez Murders (2005) reflects critically on the effects of globalisation by focusing on the impact of the Mexico-US border in women's lives. In this novel, Ivón, a lesbian Professor at an LA University, travels home to El Paso to adopt the baby of Cecilia, a maquiladora from Juarez. The novel turns into a mystery thriller after Cecilia is found dead in the desert and Ivón's sister is kidnapped in Mexico. This sequence of events leads Ivón to investigate the feminicides in Ciudad de Juárez, offering a material approach, as well as a structural analysis of how transnational flows and exchanges affect women at the Mexico-US border: "The unprecedented mobility of money, goods, and people made the Mexico-US border a paradigmatic site of new forms of governance linked to global capitalist integration" (Schmidt Camacho, 2008: 16). The suspense turns into a pretext to expose the most brutal side of globalisation, represented through the exploitation of maquiladoras.

One of the main issues tackled throughout the novel are the effects of the North American Free Trade Agreement (NAFTA) on Mexican populations. On the other hand, the establishment of US companies led to an industrialisation of the northern areas, which in turn stimulated mass movements, particularly of Mexican women searching for work in these factories. The globalising processes promoted by NAFTA not only contributed to the division of labour at a global scale, but also at the discursive and imaginary level. In these bordering regions the Catholic and traditional Mexican values encounter, clash and coexist with industrialising, globalising and capitalist forces that place women at the intersection of conflicting discourses: "The maquiladora is a site where multiple forms of both local and global oppression come together" (Mata, 2010: 22). While patriarchal discourses on gender have traditionally relegated women to the domestic realm, as well as to the roles of wives and mothers, the global division of labour relies on work carried out by poor women under 
precarious conditions, so that they essentially become constitutive components of the economic chain. This, on the other hand, implies that motherhood, which represents women's destiny in traditional patriarchal conceptions, poses a threat to the capitalist and globalising machinery. Furthermore, women's subordination and subservience, both essential to heteropatriarchal society, are at higher risk due to the proliferation of feminist discourses vindicating women's rights and agency that flourish at the borderlands. The convergence of all these contradictory messages gives rise to renewed discourses based on the imposition of fear, intimidation and violence.

While Desert Blood speculates on who might be behind these crimes, what ultimately remains of central importance is the examination of the circumstances that surrounded them and made them possible. The novel explores indirect responsibilities that point towards a conglomerate of economic, political and social interests.: "Pornographers, gang members, serial killers, corrupt policemen, foreign nationals with a taste for hurting women, immigration officers protecting the homeland -what did it matter who killed them? This wasn't a case of 'whodunit', but rather of who was allowing these crimes to happen? Whose interests were being served? Who was covering it up? Who was profiting from the deaths of all these women?" (2005: 333).

The question that Gaspar de Alba poses is not who is responsible for the crimes, but what are the circumstances that make these crimes go unpunished. This leads Ivón to investigate and expose the multiple circumstances behind the feminicides, what she refers to as "the social, political, economic, and cultural infrastructure of the US-Mexico border that makes possible for such crimes to take place with impunity" (Gaspar de Alba, 2005: v). Furthermore, the labour surplus caused by the exodus of millions of Mexican women towards industrial areas like Juarez also turns them into interchangeable pieces. By denouncing this dehumanising process, Gaspar de Alba's novel provides Juarez maquiladoras with a narrative that ultimately contributes to the restoration of their subjectivity.

Gaspar de Alba unmasks how the free market, the transnational cultural practices, and the free exchange of ideas and images, are not necessarily followed by freedom of mobility as far as human beings are concerned. The novel demonstrates that the border dividing people from Mexico and the US is barely an obstacle for companies and corporations profiting from international agreements: "Every day, all along the southern US border, international crossings with traffic lanes dedicated to NAFTA trucks facilitate the movement of tariff-free goods from Mexico to the United States and Canada. At the same time and along the same border, 9,150 Border patrol agents (...) prevent the illegal entry of immigrants" (Gallegos, 2004: 1732). Border policymaking has been informed by a dichotomy that opposes free trade policies to border control. NAFTA's free trade zone was followed in 1996 by the Illegal Immigration Reform and Immigration Responsibility Act (IIRIRA) fortifying and increasingly militarising the border. The oppressive power of the state is mirrored in the representations of how 
maquiladoras's mobility is constrained and strictly regulated, to such an extent that being on one side of the border may become a matter of life and death.

The borderlands remains a problematic zone of mobility, exchanges and transactions, as is demonstrated throughout the novel by the representation of how the exploitation of maquiladoras also has direct consequences for American women. In this sense, it is worth noting that Ivón's desire to be a mother is fulfilled thanks to a poor woman's difficulties to keep her baby. The question of privilege and the division it causes between women from various backgrounds problematise transnational connections that do not take into account material circumstances surrounding these differences. In this respect, the novel seems to remind us that, as Hernández states, "critics should concentrate not on celebrating multiculturalism but on trying to erase unjust political and economic differences that cause migratory movements and result in the severe disruption of people's lives" (2009: 18).

The impossibility to separate the Northern hemisphere from what happens in Latin America is also exposed by the impact of US foreign policy on a series of demographic changes that have altered considerably the US Latinx community. The cartography of Latinx migratory movements have been shaped by historical forces, and the displacement northwards must be taken as a response to US economic and military interventions, the "harvest of Empire" (González, 2011). US military interventions caused mass movements of Central Americans heading northwards from the 80 s onwards. Around 1 million immigrants from the seven countries that make up the Central American isthmus -Guatemala, Belize, El Salvador, Honduras, Nicaragua, Costa Rica and Panama- settled in the US between the years 1920 and 1993. With the increasing migratory movements from Central America and other Latin American and Caribbean countries from the last decades of the twentieth century, the population of largely Mexican descent became more and more heterogeneous, or in Cherrie Moraga's words, "what was once largely a Chicano/mexicano population in California is now guatemalteco, salvadoreño, nicaragüense" (1995: 213). These demographic changes permeated the cultural configuration of an increasing Latinx society: "In the midst of it all, a transnational Latino/a literary and cultural production appeared throughout the United States, one that represented recent arrivals and different issues and that was accompanied by translations of English titles into Spanish and vice versa. In many ways, US Latino/a literature as of the 1990s mirrored contemporary immigration patterns, demographic shifts, transcultural processes, and the revitalization of Spanish in the United States" (Rodríguez, Sáenz and Menjívar 2008: 211).

One of the texts that echoes the significant demographic and cultural transformations in the US as a result of the military interventions in Central America is Maya Chinchilla's collection of poems The Cha Cha Files: A Chapina Poética (2014). The four sections that make up her collection, "Solidarity Babies", "Central American Unicorns", "Homegirls and Dedications" and "Cha Cha Files" reflect on the experiences and main concerns of the Central 
American diaspora in the US, and particularly in San Francisco. Maya Chinchilla belongs to the 1.5 generation, those who moved to the United States when they were still kids and were consequently assimilated within the American educational system. Chinchilla tries to reconstruct her experience as a little girl placed in-between two imaginary worlds: her parents' homeland, back in Guatemala, and the diasporic reality she encounters in the Bay area. The narrator's double heritage generates a displacement and distress that is translated into her poems, the channel or language through which she explores the contradictions and ambiguities of living in-between two worlds, or Anzaldúa's "the borderlands".

Chinchilla coins the term "Central America-Americans" as a collective identity marker for descendants of migrants from the seven counties that make up the Central American isthmus. Her depiction of these migratory movements traces an itinerary that provides this particular group with a narrative and a place on the map. While Central America-American representations have been largely overshadowed by the influence of the population of Mexican descent within Chicanx and Latinx's discourses, Chinchilla's poems give voice to their particular concerns and experiences, delving not only into the hemispheric bonds that connect North and Central America, but also into the multiple connections within the Latinx community.

Poems like "24th \& Mission Border Transmission" offer interesting insights into transnational approaches to feminist issues. In this case, Chinchilla focuses on different expressions of violence against women in three specific contexts: Guatemala, México and Mission Street in San Francisco. While violence exerted against female bodies is understood as a phenomenon that transcends national borders, Chinchilla does not ignore that its multiple manifestations require specific and unique responses, which is not incompatible with the need to advocate for unity and consensus in condemning these brutal acts.

Guate Mala Guate Buena país eterna primavera carga nuestra pena

También México lindo y querido has some dirty secrets,

yes la madre de las tierras is helping hide our dirty laundry

out in the dessert, only half hidden,

so you know what happens to women who step out of line,

out of the house

NAFTA's neglected, unprotected, migration survival,

maquila women earning 4 dollars a day

working on electronics, working on clothes she could never afford

Explosion of exploitation!

Is only the half of it

Representing the condition

of women across the planet

(C) Servicio de Publicaciones. Universidad de Murcia. All rights reserved. IJES, vol. 21(1), 2021, pp. 1-20

Print ISSN: 1578-7044; Online ISSN: 1989-6131 
Symptom of a deeper problem.

Tener cuerpo de mujer es ser

amenazado de muerte

Her only crime, being a woman

Crimes against all out humanity

Pero sabes Qué?

!No Están Solas! !No Están Solas! !No Están Solas!

We are not alone.

(Chinchilla, 2014: 52)

This fragment denounces the inextricable link between patriarchal discourses and globalising processes, which is more specifically pointed out by the allusion to some of the effects of NAFTA, like the precarious conditions, loss of rights and economic exploitation endured by working-class Mexican women. The representation of an environment that promotes violence against women connects Chinchilla's poems with Gaspar de Alba's depiction of maquiladoras in Desert Blood. Despite their numerous differences, both works focus on how globalisation and cultural hybridity cannot be understood without reference to real and unequal power relations between countries, along with an attention to material circumstances that provide them with historical awareness.

The complex web that conjoins US foreign policy with the domestic politics in Central America causes Chinchilla to grow up in the Bay Area with an eye on her native Guatemala. The attention to transnationalism and interlatinidades ${ }^{4}$ informs Chinchilla's work, particularly her understanding of the relationships between women as traversed by solidarity. The metaphor of the bridge reappears in Chinchilla's poems. "Baby Holds Half the Sky", which opens with the verse "I was born a bridge". This poem evokes, through the confused eyes of a little girl, memories of how Maya's mother used to take her to meetings where women from different backgrounds collaborated and joined in feminist political activism. These gatherings became a source of inspiration for the author, whose poems come to represent symbolic bridges that bring together women from various backgrounds and contexts.

The sky infinite growing heavy

I would need to learn my

bridge-building skills

can unite the terrain of me

freeing up time

worrying I was meant to fall 


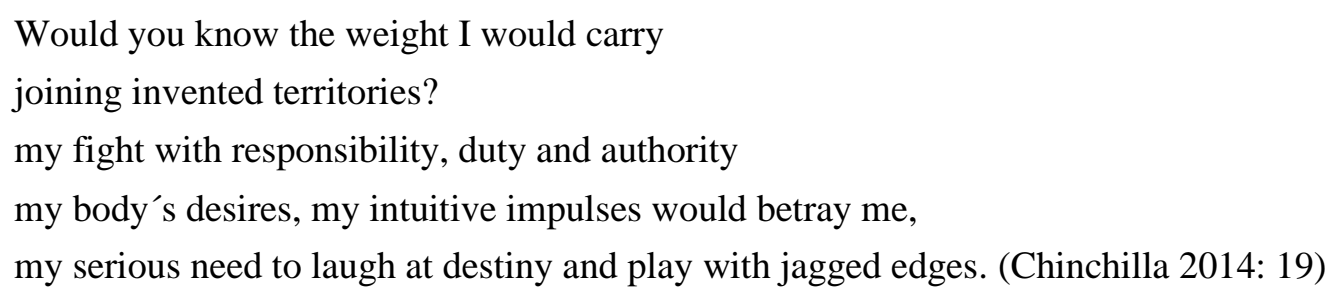

While Chinchilla's poems emphasise the real, specific and material effects of national discourses, borders and the unequal balance of power relations between different regions, her reference to "invented territories" highlights the constructed nature of nation-states. This runs parallel with a synthesis she finds between a transnational approach to feminism that transcends borders and the awareness of how material and discursive circumstances act differently upon women from various backgrounds and contexts. In this sense, her approach to transnationalism connects her to Mohanty's conception of feminism without borders, which "is not the same as 'border-less' feminism. It acknowledges the fault lines, conflicts, differences, fears, and containment that borders represent. It acknowledges that there is no one sense of a border, that the lines between and through nations, races, classes, sexualities, religions, and disabilities, are real" (2003: 2). Chinchilla's collection delves into a dilemma between an urgency to establish solidarity networks that go beyond national borders and the need to recognise diversity and differences between women that are still in some cases influenced by the central role of states.

\section{CONCLUSION}

This article gives an insight into the various ways in which the borderlands has been represented from Chicano cultural nationalism to twenty-first-century Latinx works. The selection of texts illustrates how even though the representations of the borderlands has changed in multiple ways, the relationships between Chicanx and Latinx voices and politics are always pivotal. More specifically, the emphasis on the materiality of the Mexico-US border that permeates Chicano literature is expanded by Anzaldúa's theory, which provides the theoretical grounding for Latinx writers transnational shift.

Desert Blood and Chinchilla's poems demonstrate that even within a transnational context, individual and collective identities are shaped by the materiality of borders. Furthermore, these literary representations of the borderlands evolve reflecting the political, social and economic changes at the time they were written, as can be evidenced by depictions of NAFTA at the beginning of the century and the increasing influence of Central American diasporas. The corpus of works selected mirror Schmidt Camacho's understanding of a "migrant cartography that we have come to call the transnational (...) migrant narratives speak for a new order of citizenship and shared interest, an order that follows from the struggles of people who move. It is their world-making imaginaries" (2008: 17). 
While the limited corpus of works included cannot be taken as illustrative of all cultural production written during such an extensive period of time, this article demonstrates how the representation of the borderlands in texts belonging to Chicanx and US Latinx Literature not only draws from transnational approaches but has also contributed to the development of this field of study. From this perspective, transnational and US Latinx Studies display what could be described as a symbiotic relationship in which both benefit from each other. While the "transnational, translingual and transcultural" (Mignolo, 2000: 180) experiences represented in US Latinx Literature offer a discursive space and the construction of subjectivities that defy national borders, transnational tenets acquire a more tangible shape through literary works like the ones previously analysed.

In so doing, literature draws new maps that trace imaginary connections between different groups, while taking into consideration materialistic conditions that vary according to the various individual and collective experiences. Latinx Literature and transnational studies become intertwined, allowing a narrative response to Rodríguez's question: "How would intersecting Latin American diasporas figure into the preexisting US cultural and ethnic imaginary? What would a more pluralistic Latino cultural imaginary look like, sound like, feel like, and embody as a whole? Indeed, new terms would have to be invented to articulate and represent new Latino social constructs in the making" (2003: 212).

\section{ACKNOWLEDGEMENTS}

This research is part of the project financed by MINECO and FEDER, "NEW WESTS: El Oeste americano en la literatura, el cine y la cultura del siglo XXI: un enfoque transnacional y transdisciplinar", with the code PGC2018-094659-B-C21 (MCIU/AEI/FEDER,UE). It is also part of the project I+D+i "Poéticas del activismo: Interseccionalidades Culturales y Literarias en el Mundo Contemporáneo" by the Conselleria de Educación, Investigación of the Generalitat Valenciana.

\section{NOTES}

${ }^{1}$ This research is part of the project financed by MINECO and FEDER, "NEW WESTS: El Oeste americano en la literatura, el cine y la cultura del siglo XXI: un enfoque transnacional y transdisciplinar", with the code PGC2018-094659-B-C21 (MCIU/AEI/FEDER,UE). It is also part of the project I+D+i "Poéticas del activismo: Interseccionalidades Culturales y Literarias en el Mundo Contemporáneo" by the Conselleria de Educación, Investigación of the Generalitat Valenciana.

${ }^{2}$ In Chicano Folkore (2001) Rafaela Castro suggests that the term Chicano may be either a mixture between the word mexicano and the city of Chihuahua, or the result of the Spanish word "chico".

${ }^{3}$ Homi Bhabha defines hybridity as a process that rises beyond dualisms to give "rise to something different, something new and unrecognizable, a new area of negotiation of meaning and representation" (Bhabha in Rutherford, 1990: 211). 
${ }^{4}$ Frances Aparicio uses "interlatinidades" as a category that reflects "the very complex and interestingly novel ways in which Latino/as from specific national groups get to know, and interact with, their cultural twins and national others" (2000: 6).

\section{REFERENCES}

Alexander, J. (2005). Pedagogies of Crossing: Meditations on Feminism, Sexual Politics, Memory, and the Sacred. Durham: Duke UP.

Anaya, R. (1972). Bless Me, Última. Berkeley: Warner Books.

Anzaldúa, G. (1987). Borderlands/La Frontera: The New Mestiza. San Francisco: Aunt Lute Books.

Aparicio, F. (2000). Cultural Twins and National Others: Literary Allegories of Interlatino/a Subjectivities. Paper presented at Chicano/ Latino Research Center Working Paper Series. University of California-Santa Cruz.

---. (2003). Latino Cultural Studies. In J. Poblete (Ed), Critical Latin America and Latino Studies (pp. 3-32). Minneapolis: U of Minnesota P.

Bolton, H. (1921). The Spanish Borderlands. A Chronicle of Old Florida and the SouthWest. New Haven: Yale UP.

Briggs, L., G. McCormick \& Way, J.T. (2008). Transnationalism: A Category of Analysis. American Quarterly, 60(3), 625-648.

Calderón, H and J. Saldívar. (1991). Criticism in the Borderlands: Studies in Chicano Literature, Culture and Ideology. Durham: Duke UP.

Campbell, N. (2008). The Rhizomatic West: Representing the American West in a Transnational, Global, Media Age. Lincoln: U of Nebraska P.

Castro, R. (2001). Chicano Folklore. Oxford: Oxford UP.

Chabram-D. (1994). A. Chicana! Rican? No, Chicana-Riqueña! Refashioning the Transnational Connection". In D.T. Goldberg (Ed), Multiculturalism: A Critical Reader (pp. 269-295). London: Blackwell Press.

Chinchilla, M. (2014). The Cha Cha Files: A Chapina Poética. San Francisco: Korima P.

Ethington, P. (1996). Toward a Borderland School for American Urban Ethnic Studies. American Quarterly, 48(2), 344-353.

García, A. (1989). The Development of Chicana Feminist Discourse, 1970-1980. Gender \& Society, 3(2), 217-238.

García-Avello, M. (2019). Beyond the Latina Boom: New Directions Within the Field of US Latina Literature. Atlantis, 41(1), 69-87.

Gaspar de Alba, A. (2005). Desert Blood: The Juarez Murders. Houston: Arte Público. 
Griswold del Castillo, R. (1984). Reviewed Works: Al Norte del Róo Bravo (Pasado Inmediato, 1930-1981) by David Maciel. Latin American Research Review, 19(1), 199-209.

Groenewold, M. (2005). Chicana Feminism: Self-Actualization Through Border Conscience. Intercultural Communication Studies, xiv(3), 92-100.

Hanke, L. (1964). Do the Americas Have a Common History?: A Critique of the Bolton Theory. New York: Knopf.

Hernández, E. (2009). Postnationalism in Chicanalo Literature and Culture. Austin: U of Texas $\mathrm{P}$.

Ibarrarán, A. (2009). Yxta Maya Murray’s Locas (1997) and What about Chicana Barrio Adolescents? Babel Afial, 18, 35-48.

Kaplan, C., N. Alarcón \& Moallen, M. (1999). Between Woman and Nation. Durham: Duke UP.

Leonard, D. \& Lugo-Lugo, C. R. (Eds). (2010). Latino. History and Culture: An Encyclopedia. London and New York: Routledge.

Lytle Hernández, K. (2011). Borderlands and the Future History of the American West. The Western Historical Quarterly, 42(3), 325-330.

Lorde, A. (1982/ 2001). Zami: A New Spelling of My Name. Berkeley: Crossing P.

Mata, I. (2010). Writing on the Walls: Deciphering Violence and Industrialization in Alicia Gaspar de Alba's Deser Blood. MELUS: Multi-Ethnic Literature of the US, 35, $15-40$.

Mignolo, W. (2000). Human Understanding and (Latin) American Interests- The Politics and Sensibilities of Geohistorical Locations. In H. Schwarz \& Ray S. (Eds), A Companion to Post-Colonial Studies (pp. 180-203). Cornwall: Blackwell Publishing Ltd.

Moghadam, V. (2005). Globalizing Women: Transnational Feminist Networks. Baltimore: John Hopkins UP.

Mohanty, C. (2003). Feminism Without Borders: Decolonizing Theory, Practicing Solidarity. Durham: Duke UP.

Moraga, C. \& Anzaldúa, G. (1981). This Bridge Called My Back: Writings By Radical Women of Color. New York: Kitchen Table: Women of Color P.

---. (1995). Art in America con Acento. In L. Castillo-Speed (Ed), Latina: Women's Voices from the Borderlands (pp. 210-220). New York: Touchstone Books.

Mujcinovic, F. (2004). Postmodern Cross-Culturalism and Politicization in U.S. Latina Literature. New York: Peter Lang.

Paredes, R. (1988). Mexican American Literature. In E. Elliot (Ed), Columbia Literary History of the United States (pp. 800-810). New York: Columbia UP. 
Poblete, J. (Ed). (2003). Critical Latin America and Latino Studies. Minneapolis: U of Minnesota P.

Ramamurthy, P. (2003). Material Consumers, Fabricating Subjects: Perplexity, Global Connectivity Discourses, and Transnational Feminist Research. Cultural Anthropology, 18(4), 524-550.

Rutherford, J. (1990). The Third Space. Interview with Homi Bhabha. In J. Rutherford (Ed), Community, Culture, Difference (pp. 207-221). London: Lawrence and Wishart.

Rivera, T. (1971). ...Y no se lo tragó la tierra. Berkeley: Quinto Sol Publications.

Rodríguez, A. M. (2003). Queer Latinidades. Identity Practices, Discursive Spaces. New York: New York UP.

Rodríguez, H., R. Saenz \& C. Menjívar (2008). Latinos in the United States: Changing the Face of América. New York: Springer.

Román-Odio, C. \& Sierra, M. (2011). Transnational Borderlands in Women's Global Networks: The Making of Cultural Resistance. New York: Palgrave Macmillan.

Saldívar, J. (1997). Border Matters. Remapping American Cultural Studies. Berkeley: U of California P.

Sánchez, G. (1995). Becoming Mexican American. Ethnicity, Culture and Identity in Chicano Los Angeles 1900-1945. Oxford: Oxford UP.

Schmidt Camacho, A. (2008). Migrant Imaginaries: Latino Cultural Politics in the U.S. Mexico Borderlands. New York: New York UP.

Smith, A \& Franco, A. (2018). The Politics of Latinx Literature Today. Chiricú Journal, Latina/o Literatures, Arts, and Cultures, 2(2), 5-19.

Vallejos, T. (1989). Jose Antonio Villareal. In A. Lomeli \& C. Shirley (Eds), Chicano Writers: First Series (pp. 282-288). Detroit: Gale Research.

Vázquez, D. (2013). Novel. In S. Bost \& F. R. Aparicio (Eds), The Routledge Companion to Latino/a Literature (pp. 299-309). New York: Routledge.

Vertovec, S. (2009). Transnationalism. New York: Routledge.

Villareal, J. (1959/1970). Pocho. New York: Anchor.

Walter, R. (2003). Narrative Identities: (Inter) Cultural in-Betweenness in the Americas. Bern: Peter Lang.

Yarbro-Bejarano, Y. (1994). Gloria Anzaldúa's Boderlands/ La frontera: Cultural Studies, "Difference," and the Non-Unitary Subject. Cultural Critique, 28, 5-28. 